\title{
Association of Heavy Metals with Overall Mortality in a Taiwanese Population
}

Yi-hsueh Liu ( $\sim$ liuboy17@gmail.com )

Kaohsiung Municipal Siaogang Hospital https://orcid.org/0000-0001-6915-3679

Chih-Wen Wang

Kaohsiung Municipal Siaogang Hospital

Da-Wei Wu

Kaohsiung Municipal Siaogang Hospital

Wen-Hsien Lee

Kaohsiung Municipal Siaogang Hospital

Ying-Chih Chen

Kaohsiung Municipal Siaogang Hospital

Chiu-Hui Li

Kaohsiung Municipal Siaogang Hospital

Chun-Chi Tsai

Kaohsiung Municipal Siaogang Hospital

Wen-Yi Lin

Kaohsiung Municipal Siaogang Hospital

Szu-Chia Chen

Kaohsiung Municipal Siaogang Hospital

Chih-Hsing Hung

Kaohsiung Municipal Siaogang Hospital

Chao-Hung Kuo

Kaohsiung Municipal Siaogang Hospital

Ho-Ming Su

Kaohsiung Municipal Siaogang Hospital

\section{Research Article}

Keywords: Heavy Metals, Mortality, Taiwanese Population, Cadmium, Copper, Manganese

Posted Date: March 16th, 2021

DOI: https://doi.org/10.21203/rs.3.rs-277882/v1 
License: (c) (i) This work is licensed under a Creative Commons Attribution 4.0 International License. Read Full License 


\section{Abstract}

Previous studies have shown links between heavy metals and many health issues. However, data on the association between heavy metals and mortality in the general population are still limited. Therefore, the aim of this study was to investigate the relationship between heavy metals and overall mortality in the general population. We enrolled 2,497 participants (1,001 males and 1,496 females) living in southern Taiwan, and measured levels of seven heavy metals: lead $(\mathrm{Pb})$ in blood and cadmium $(\mathrm{Cd})$, nickel $(\mathrm{Ni})$, copper $(\mathrm{Cu})$, chromium $(\mathrm{Cr})$, manganese $(\mathrm{Mn})$ and arsenic $(\mathrm{As})$ in urine. The median follow-up period was 41.8 (4-50) months, during which 40 (1.6\%) patients died. Compared to the participants who survived, those who died had higher urine $\mathrm{Cd}$, higher urine $\mathrm{Cu}$ and lower urine $\mathrm{Mn}$ levels. Multivariate analysis showed that high urine $\mathrm{Cd}$ (per $1 \mathrm{mg} / \mathrm{L}$; hazard ratio [HR], 1.352; 95\% confidence interval [Cl], 1.089-1.680; $p=0.006$ ), high urine $\mathrm{Cu}$ (per $1 \mathrm{mg} / \mathrm{dL} ; \mathrm{HR}, 1.350 ; 95 \% \mathrm{Cl}, 1.151-1.583 ; p<0.001$ ), and low urine Mn (per 1 $\mathrm{mg} / \mathrm{L} ; \mathrm{HR}, 0.717 ; 95 \% \mathrm{Cl}, 0.557-0.923 ; p=0.010$ ) were associated with increased overall mortality. In conclusion, our results demonstrated that high levels of urine $\mathrm{Cd}$ and $\mathrm{Cu}$ and low urine $\mathrm{Mn}$ level were associated with increased overall mortality in general population.

\section{Introduction}

Heavy metals are defined as metallic elements that have a relatively high density compared to water. Some metals such as zinc, copper $(\mathrm{Cu})$, iron, manganese $(\mathrm{Mn})$, and cobalt are required for various biochemical and physiological functions in humans at low concentrations, but they become toxic at higher concentrations. Other heavy metals such as lead (Pb), mercury, and cadmium (Cd) are not known to have any beneficial effects on human health and their accumulation in the human body is deleterious to human health(Rehman et al. 2018). Heavy metals are common environmental contaminants and toxicity due to heavy metals is a growing concern(Jaishankar et al. 2014). Heavy metals can disrupt metabolic functions through various mechanisms and their toxicity depends on factors such as dose, chemical form, and route of exposure, in addition to age, sex, and nutritional and genetic status of the exposed individual(Tchounwou et al. 2012). Moreover, heavy metals can accumulate in organs such as liver, heart, kidneys, and brain and disrupt normal biological functions.

Some heavy metals such as arsenic (As), $\mathrm{Cd}$, chromium ( $\mathrm{Cr}$ ), $\mathrm{Pb}$, and mercury, are systemic toxicants, which have been shown to cause adverse health effects in humans, including developmental abnormalities, cardiovascular diseases, renal injury, neurologic and neurobehavioral disorders, diabetes, hematologic and immunologic disorders, and various types of cancer(Tchounwou et al. 2012). Heavy metal-induced toxicity has been shown to be through the production of reactive oxygen species, resulting in oxidative damage and adverse effects on health(Rehman et al. 2018). Previous studies have reported associations between mortality and various heavy metals. For example, $\mathrm{Pb}$ exposure has been shown to be a risk factor for cardiovascular mortality and even a low blood $\mathrm{Pb}$ concentration has been associated with increased risks of all-cause mortality, cardiovascular disease, and cancer(Byun et al. 2020; Lanphear et al. 2018; Lustberg and Silbergeld 2002; Schober et al. 2006). In addition, exposure to low concentrations of $\mathrm{Cd}$ has also been associated with increased risks of overall and cardiovascular 
mortality(Larsson and Wolk 2016; Menke et al. 2009; Tellez-Plaza et al. 2012; Wang et al. 2011). For nickel $(\mathrm{Ni})$, increased rates of mortality and cancer have been reported in Ni workers and people living in highly polluted environments(Chen et al. 2015; Huang et al. 2013; Khlifi et al. 2013; Lightfoot et al. 2010). Chronic As exposure through contaminated drinking water has also been associated with increase allcause and chronic disease-related mortality(Argos et al. 2010; Meliker et al. 2007). In addition, several studies have reported potential associations between high serum $\mathrm{Cu}$ concentrations and increased overall, cancer, and cardiovascular-related mortality(Eshak et al. 2018; Grammer et al. 2014; Leone et al. 2006; Wu et al. 2004).

Although the effects of heavy metals on human health have been widely discussed in the literature, studies on the effect of heavy metal concentrations within relative normal limits on mortality in the general population are still limited. Therefore, the aim of this study was to investigate the relationships between heavy metals, including $\mathrm{Pb}$ in blood, and $\mathrm{Cd}, \mathrm{Ni}, \mathrm{Cu}, \mathrm{Cr}, \mathrm{Mn}$, and $\mathrm{As}$ in urine with overall mortality in people living in southern Taiwan.

\section{Materials And Methods}

\section{Subject Recruitment}

We conducted a health survey from June 2016 to September 2018 in southern Taiwan, which was promoted thorough advertisements. All subjects who attended the health survey and were willing to participate in this study were enrolled. Subsequently, they all underwent physical examinations and an experienced physician recorded their clinical histories. Anthropometric measurements including systolic blood pressure, diastolic blood pressure, and weight and height were taken.

\section{Ethics Statement}

The study protocol was approved by the Institutional Review Board of Kaohsiung Medical University Hospital (number: KMUHIRB-G(II)-20190011).

All participants provided informed consent before study enrollment.

\section{Collection of Demographic, Medical, and Laboratory Data}

In addition to the anthropometric measurements, the following variables were recorded at baseline: demographics (age and sex), medical history (diabetes mellitus [DM], hypertension, hyperlipidemia, and laboratory data (fasting glucose, serum creatinine, triglycerides, total cholesterol, high [HDL]- and low density lipoprotein [LDL]-cholesterol). Body mass index (BMI) was calculated as weight/height squared $\left(\mathrm{kg} / \mathrm{m}^{2}\right)$.

\section{Measurement of Blood and Urine Heavy Metal Concentrations}


The concentrations of seven heavy metals ( $\mathrm{Pb}$ in blood and $\mathrm{Cd}, \mathrm{Ni}, \mathrm{Cu}, \mathrm{Cr}, \mathrm{Mn}$, and $\mathrm{As}$ in urine) were measured using graphite furnace atomic absorption spectrometry (ICP-MS, NexION 300 Series, Perkin Elmer). Details of this analysis have been reported by the National Institute of Environmental Research.

\section{Definition of Overall Mortality}

Data on overall mortality were collected from the Collaboration Center of Health Information Application (CCHIA), Ministry of Health and Welfare, Executive Yuan, Taiwan, up to July 2020.

\section{Statistical Analysis}

Statistical analysis was performed using SPSS version 22.0 for Windows (SPSS Inc. Chicago, USA). Data were expressed as percentages, means \pm standard deviations, or medians (25th -75 th percentiles) for heavy metals. Between-group differences in categorical variables were analyzed using the chi-square test and between-group differences in continuous variables were analyzed using the independent $t$ test. Multivariate Cox proportional hazard analysis was used to identify associations between the heavy metals and overall mortality. Significant variables in univariate analysis were entered into the multivariate analysis. A $p$ value of less than 0.05 was considered to indicate a statistically significant difference.

\section{Results}

The mean age of the 2,497 participants ( 1,001 males and 1,496 females) was $54.3 \pm 14.0$ years. A comparison of the clinical characteristics between the survivors and non-survivors is shown in Table 1. Compared to the survivors, the non-survivors were older and had higher prevalence rates of DM and hypertension, a higher level of creatinine, and lower level of LDL-cholesterol. In addition, the non-survivors had higher urinary concentrations of $\mathrm{Cd}$ and $\mathrm{Cu}$ and a lower urinary concentration of $\mathrm{Mn}$. 
Table 1

Comparison of clinical characteristics between the survivors and non-survivors

\begin{tabular}{|c|c|c|c|c|}
\hline Characteristics & All $(n=2,497)$ & Survival $(n=2,457)$ & Death $(n=40)$ & $p$ \\
\hline Age (year) & $54.3 \pm 14.0$ & $54.1 \pm 14.0$ & $69.1 \pm 11.4$ & $<0.001$ \\
\hline Male gender (\%) & 40.1 & 40.0 & 45.0 & 0.523 \\
\hline DM (\%) & 10.3 & 9.9 & 32.5 & 0.005 \\
\hline Hypertension (\%) & 24.8 & 24.3 & 55.0 & $<0.001$ \\
\hline Hyperlipidemia (\%) & 2.2 & 2.2 & 2.5 & 0.912 \\
\hline $\mathrm{BMI}\left(\mathrm{kg} / \mathrm{m}^{2}\right)$ & $25.0 \pm 3.9$ & $25.0 \pm 3.9$ & $25.2 \pm 4.5$ & 0.834 \\
\hline $\mathrm{SBP}(\mathrm{mmHg})$ & $131.8 \pm 19.8$ & $131.7 \pm 19.7$ & $137.2 \pm 21.3$ & 0.083 \\
\hline $\mathrm{DBP}(\mathrm{mmHg})$ & $77.4 \pm 11.7$ & $77.4 \pm 11.7$ & $78.1 \pm 11.6$ & 0.691 \\
\hline \multicolumn{5}{|l|}{ Laboratory parameters } \\
\hline Fasting glucose (mg/dL) & $99.6 \pm 27.2$ & $99.5 \pm 27.1$ & $106.9 \pm 31.7$ & 0.087 \\
\hline $\begin{array}{l}\text { Serum Creatinine } \\
(\mathrm{mg} / \mathrm{dL})\end{array}$ & $0.95 \pm 0.29$ & $0.94 \pm 0.28$ & $1.18 \pm 0.53$ & 0.007 \\
\hline Triglyceride (mg/dL) & $126.1 \pm 97.4$ & $126.0 \pm 97.3$ & $138.2 \pm 100.2$ & 0.428 \\
\hline Total cholesterol (mg/dL) & $199.2 \pm 37.5$ & $199.3 \pm 37.4$ & $191.4 \pm 43.3$ & 0.186 \\
\hline HDL-cholesterol (mg/dL) & $53.0 \pm 13.6$ & $53.0 \pm 13.6$ & $50.5 \pm 15.4$ & 0.237 \\
\hline LDL-cholesterol (mg/dL) & $118.9 \pm 34.0$ & $119.1 \pm 33.9$ & $108.4 \pm 36.1$ & 0.048 \\
\hline \multicolumn{5}{|l|}{ Blood } \\
\hline $\mathrm{Pb}(\mu \mathrm{g} / \mathrm{dL})$ & $1.5(1.0-2.2)$ & $1.8(1.0-2.2)$ & $2.1(1.3-2.8)$ & 0.201 \\
\hline \multicolumn{5}{|l|}{ Urine } \\
\hline $\mathrm{Cd}(\mu \mathrm{g} / \mathrm{L})$ & $0.8(0.3-1.4)$ & $1.1(0.2-1.4)$ & $1.5(0.5-2.4)$ & 0.017 \\
\hline $\mathrm{Ni}(\mu \mathrm{g} / \mathrm{L})$ & $2.5(1.5-3.7)$ & $3.3(1.5-3.7)$ & $3.8(1.9-5.4)$ & 0.829 \\
\hline $\mathrm{Cu}(\mu \mathrm{g} / \mathrm{dL})$ & $1.5(1.0-2.0)$ & $1.6(1.0-2.0)$ & $2.55(1.5-3.6)$ & $<0.001$ \\
\hline $\mathrm{Cr}(\mu \mathrm{g} / \mathrm{L})$ & $0.1(0.1-0.1)$ & $0.1(0.1-0.1)$ & $0.1(0.1-0.1)$ & 0.787 \\
\hline $\mathrm{Mn}(\mu \mathrm{g} / \mathrm{L})$ & $1.7(0.9-3.0)$ & $2.2(0.9-3.0)$ & $1.5(0.6-2.0)$ & 0.019 \\
\hline As $(\mu \mathrm{g} / \mathrm{L})$ & $\begin{array}{l}77.9(44.5- \\
140.2)\end{array}$ & $118.2(44.0-139.4)$ & $159.9(69.9-205.4)$ & 0.064 \\
\hline
\end{tabular}




\section{Predictors of Overall Mortality}

The median follow-up period was 41.8 (range 4-50) months for all participants, during which 40 (1.6\%) patients died. Table 2 shows the associations among demographic, medical, laboratory, and heavy metal data with overall mortality. In the univariate analysis, old age (per 1 year; hazard ratio [HR], 1.097; 95\% confidence interval [Cl], 1.066-1.128; $p<0.001)$, DM (HR, 4.049; 95\% Cl, 2.089-7.848; $p<0.001)$, hypertension (HR, 3.478; $95 \% \mathrm{Cl}, 1.865-6.485 ; p<0.001$ ), high serum creatinine (per $1 \mathrm{mg} / \mathrm{dL} ; \mathrm{HR}, 1.998$; 95\% Cl, 1.482-2.695; $p<0.001$ ), low LDL-cholesterol (per $1 \mathrm{mg} / \mathrm{dL} ; \mathrm{HR}, 0.990 ; 95 \% \mathrm{Cl}, 0.980-0.999 ; p=$ 0.037), high urine $\mathrm{Cd}$ (per $1 \mu \mathrm{g} / \mathrm{L} ; \mathrm{HR}, 1.290 ; 95 \% \mathrm{Cl}, 1.070-1.554 ; p=0.008)$, high urine $\mathrm{Cu}$ (per $1 \mu \mathrm{g} / \mathrm{dL}$; $\mathrm{HR}, 1.378 ; 95 \% \mathrm{Cl}, 1.241-1.549 ; p<0.001$ ), and low urine $\mathrm{Mn}$ (per $1 \mu \mathrm{g} / \mathrm{L} ; \mathrm{HR}, 0.726 ; 95 \% \mathrm{Cl}, 0.567-0.930$; $p=0.011)$ were associated with increased overall mortality. 
Table 2

Predictors of overall mortality using Cox proportional hazards model

\begin{tabular}{|c|c|c|}
\hline \multirow[t]{2}{*}{ Parameters } & \multicolumn{2}{|l|}{ Univariable analysis } \\
\hline & $\mathrm{HR}(95 \% \mathrm{Cl})$ & $p$ \\
\hline Age (per 1 year) & $1.097(1.066-1.128)$ & $<0.001$ \\
\hline Male (vs. female) & $1.259(0.675-2.347)$ & 0.469 \\
\hline DM & $4.049(2.089-7.848)$ & $<0.001$ \\
\hline Hypertension & $3.478(1.865-6.485)$ & $<0.001$ \\
\hline Hyperlipidemia & $1.193(0.164-8.685)$ & 0.862 \\
\hline BMI (per 1 kg/m²) & $1.007(0.929-1.090)$ & 0.873 \\
\hline SBP (per 1 mmHg) & $1.012(0.998-1.027)$ & 0.090 \\
\hline DBP (per 1 mmHg) & $1.007(0.981-1.033)$ & 0.615 \\
\hline \multicolumn{3}{|l|}{ Labortaory data } \\
\hline Fasting glucose (per 1 mg/dL) & $1.006(0.998-1.014)$ & 0.141 \\
\hline Creatinine (per 1 mg/dL) & $1.998(1.482-2.695)$ & $<0.001$ \\
\hline Total cholesterol (per $1 \mathrm{mg} / \mathrm{dl}$ ) & $0.994(0.985-1.002)$ & 0.155 \\
\hline Triglyceride (per 1 mg/dL) & $1.001(0.999-1.003)$ & 0.366 \\
\hline HDL-cholesterol (per 1 mg/dL) & $0.986(0.962-1.010)$ & 0.254 \\
\hline LDL-cholesterol (per 1 mg/dL) & $0.990(0.980-0.999)$ & 0.037 \\
\hline \multicolumn{3}{|l|}{ Blood } \\
\hline $\mathrm{Pb}($ per $1 \mu \mathrm{g} / \mathrm{dL})$ & $1.067(0.931-1.222)$ & 0.350 \\
\hline \multicolumn{3}{|l|}{ Urine } \\
\hline Cd (per $1 \mu \mathrm{g} / \mathrm{L})$ & $1.290(1.070-1.554)$ & 0.008 \\
\hline $\mathrm{Ni}($ per $1 \mu \mathrm{g} / \mathrm{L})$ & $1.001(0.989-1.013)$ & 0.866 \\
\hline $\mathrm{Cu}($ per $1 \mu \mathrm{g} / \mathrm{dL}$ & $1.378(1.241-1.529)$ & $<0.001$ \\
\hline $\operatorname{Cr}($ per $1 \mu \mathrm{g} / \mathrm{L})$ & $1.101(0.534-2.268)$ & 0.795 \\
\hline Mn (per $1 \mu \mathrm{g} / \mathrm{L})$ & $0.726(0.567-0.930)$ & 0.011 \\
\hline As (per $1 \mu \mathrm{g} / \mathrm{L}$ ) & $1.001(1.000-1.003)$ & 0.127 \\
\hline
\end{tabular}


In the multivariate Cox proportional hazard analysis, after adjusting for age, DM, hypertension, serum creatinine, and LDL-cholesterol, high urine $\mathrm{Cd}$ (per $1 \mu \mathrm{g} / \mathrm{L} ; \mathrm{HR}, 1.352 ; 95 \% \mathrm{Cl}, 1.089-1.680 ; p=0.006$ ), high urine $\mathrm{Cu}$ (per $1 \mu \mathrm{g} / \mathrm{dL} ; \mathrm{HR}, 1.350 ; 95 \% \mathrm{Cl}, 1.151-1.583 ; p<0.001$ ), and low urine Mn (per $1 \mu \mathrm{g} / \mathrm{L} ; \mathrm{HR}, 0.717$; $95 \% \mathrm{Cl}, 0.557-0.923 ; p=0.010$ ) were significantly associated with increased overall mortality (Table 3 ).

Table 3

Association of heavy metals with overall mortality using multivariate Cox proportional hazards model

\begin{tabular}{|c|c|c|}
\hline \multirow[t]{2}{*}{ Heavy metals } & \multicolumn{2}{|l|}{ Multivariable } \\
\hline & $\mathrm{HR}(95 \% \mathrm{Cl})$ & $p$ \\
\hline \multicolumn{3}{|l|}{ Blood } \\
\hline $\mathrm{Pb}($ per $1 \mu \mathrm{g} / \mathrm{dL})$ & $1.024(0.865-1.231)$ & 0.780 \\
\hline \multicolumn{3}{|l|}{ Urine } \\
\hline Cd (per $1 \mu \mathrm{g} / \mathrm{L})$ & $1.352(1.089-1.680)$ & 0.006 \\
\hline $\mathrm{Ni}($ per $1 \mu \mathrm{g} / \mathrm{L})$ & $1.004(0.990-1.018)$ & 0.599 \\
\hline Cu (per $1 \mu \mathrm{g} / \mathrm{dL})$ & $1.350(1.151-1.583)$ & $<0.001$ \\
\hline $\operatorname{Cr}($ per $1 \mu \mathrm{g} / \mathrm{L})$ & $1.015(0.513-2.009)$ & 0.966 \\
\hline 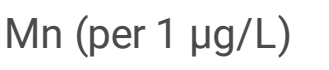 & $0.717(0.557-0.923)$ & 0.010 \\
\hline As $($ per $1 \mu \mathrm{g} / \mathrm{L})$ & $1.001(0.999-1.003)$ & 0.424 \\
\hline
\end{tabular}

Values expressed as hazard ratio (HR) and 95\% confidence interval (Cl). Abbreviations are the same as in Table 1.

Covariates in the multivariable model included age, sex, DM, hypertension, creatinine, and LDLcholesterol.

\section{Discussion}

In this study, we evaluated the relationships between heavy metals and overall mortality in 2,497 participants living in southern Taiwan and found that high urine $\mathrm{Cd}$, high urine $\mathrm{Cu}$, and low urine $\mathrm{Mn}$ were associated with increased overall mortality.

The first important finding of this study is that high urine $\mathrm{Cd}$ was associated with increased overall mortality. $\mathrm{Cd}$ is a non-essential nutrient and an extremely toxic industrial and environmental pollutant which is classified as a human carcinogen(Faroon et al. 2012). Cigarette smoke is a major source of $\mathrm{Cd}$ exposure and food is the major source of Cd exposure in non-smokers(Genchi et al. 2020). Cd compounds are mainly used in re-chargeable $\mathrm{Ni}$-Cd batteries and emissions of $\mathrm{Cd}$ have increased substantially in the 20th century(Jarup 2003). As urinary Cd excretion is slow, Cd accumulates in the body, particularly in the kidneys and liver, with a reported biological half-life of 10-30 years(Faroon et al. 2012). Chronic Cd toxicity has been associated with renal tubular dysfunction, reduced bone mineral 
density, normochromic anemia, and some cancers(Jarup 2002). In the present study, we found that high urine $\mathrm{Cd}$ was associated with increased overall mortality, which is consistent with previous studies(Larsson and Wolk 2016; Menke et al. 2009; Ruiz-Hernandez et al. 2017; Tellez-Plaza et al. 2012; Wang et al. 2011). There is no margin of safety between exposure and the point of departure in the general population, and therefore it is important to limit exposure to $\mathrm{Cd}$ as far as possible(Jarup and Akesson 2009).

The second important finding of this study is that high urine Cu was correlated with increased overall mortality. $\mathrm{Cu}$ is common in the environment and an essential nutrient. $\mathrm{Cu}$ acts as a critical cofactor and plays important roles in many metalloenzymes involved in drug metabolism, hemoglobin formation, pigment formation, cellular respiration, iron oxidation, carbohydrate metabolism, catecholamine biosynthesis, connective tissue formation, and antioxidant defense mechanisms(Dorsey and Ingerman 2004; Madsen and Gitlin 2007). The most common routes of exposure to $\mathrm{Cu}$ in humans are through inhalation, oral intake, and dermal contact, but mainly through food. Cu is taken up by the liver and excreted in bile or secreted into plasma(Gaetke and Chow 2003). The most sensitive adverse effect of excess exposure to $\mathrm{Cu}$ is gastrointestinal tract irritation, causing acute nausea, vomiting, and diarrhea (Taylor et al. 2020). At higher doses, Cu toxicity can cause headache, gastrointestinal hemorrhage, hemolytic anemia, and liver and kidney failure(Scheiber et al. 2013). Cu is not known to be carcinogenic or mutagenic or to have reproductive or in utero effects(Taylor et al. 2020). On the other hand, $\mathrm{Cu}$ deficiency can cause anemia, leucopenia, and myeloneuropathy(Wazir and Ghobrial 2017). In the present study, high urine Cu was associated with an increase in mortality, which is consistent with previous studies(Eshak et al. 2018; Grammer et al. 2014; Leone et al. 2006; Wu et al. 2004). The mechanism for this increase in mortality is unclear, however it may be related to increased inflammation, oxidative stress, or the metabolic syndrome(Bo et al. 2008; Wen et al. 2020). High concentrations of Cu have been shown to potentially cause oxidative damage to proteins, lipids, and DNA and also to play a role in neurodegenerative disorders(Gaetke and Chow 2003).

Another important finding of this study is that low urine $\mathrm{Mn}$ was associated with increased overall mortality. $\mathrm{Mn}$ is an essential nutrient that plays a role in growth and tissue formation, metabolism, and reproduction(Chen et al. 2018; Wu et al. 2017). Mn is mainly absorbed through the gastrointestinal tract, but also through inhalation and intravenous routes(O'Neal and Zheng 2015). Mn is primarily eliminated via fecal hepatobiliary excretion and to a lesser extent urinary excretion. Mn deficiency is rare and is related to reduced fertility, deficient bone formation, impaired growth, skeletal defects, birth defects, altered lipid and carbohydrate metabolism, and abnormal glucose tolerance in both animals and humans(Li and Yang 2018). Mn is a cofactor in various enzymes and plays crucial roles in reproduction, development, digestion, energy production, antioxidant defense, regulation of neuronal activities, and immune responses(Chen et al. 2018), which may partially explain our present finding, i.e. low urine $\mathrm{Mn}$ was associated with increased overall mortality.

There are several limitations to this study. First, the follow-up period was relatively short, and a longer follow-up period may provide a better understanding of the associations between heavy metal 
concentrations and mortality. Nevertheless, our findings highlight the important link between heavy metals and mortality. Second, we could not identify the sources or routes of heavy metal exposure in our study cohort. Even though we measured blood and urinary concentrations of the heavy metals and obtained serum biochemical data, different exposure methods and routes may have different effects. Finally, we measured total As concentrations but could not measure level of inorganic As in urine due to limitations in our equipment, and this may have led to an underestimation of the contribution of As on mortality.

In conclusion, our results demonstrated that in general population, high urine $\mathrm{Cd}$ and $\mathrm{Cu}$ and low urine $\mathrm{Mn}$ were associated with increased overall mortality.

\section{Declarations}

\section{Ethics declarations}

\section{Ethics approval and consent to participate}

The study protocol was approved by the Institutional Review Board of Kaohsiung Medical University Hospital (number: KMUHIRB-G(II)-20190011). All participants provided informed consent before study enrollment.

\section{Consent for publication}

Not applicable.

\section{Availability of data and materials}

The datasets used and analyzed during the current study are available from the corresponding author on reasonable request.

\section{Competing interest}

The authors declare that they have no known competing financial interests or personal relationships that could have appeared to influence the work reported in this paper.

\section{Funding}

The research presented in this article is supported by the grant from Kaohsiung Municipal Hsiao-Kang Hospital (kmhk-109-008), Kaohsiung Medical University, Kaohsiung, Taiwan.

\section{Acknowledgements}

Mortality data were provided by the Collaboration Center of Health Information Application, Ministry of Health and Welfare, Executive Yuan. 


\section{Author's contributions}

Yi-Hsueh Liu reviewed the articles and wrote the manuscript. Chih-Wen Wang, Da-Wei Wu, and Wen-Hsien Lee analyzed and interpreted the data. Ying-Chih Chen, Chiu-Hui Li, Chun-Chi Tsai, and Wen-Yi Lin provided consultation and validation. Szu-Chia Chen, Chih-Hsing Hung, and Chao-Hung Kuo supervised the work. Ho-Ming Su revised the manuscript draft and the final version of the submitted manuscript. All authors read and approved the final manuscript.

\section{References}

Argos $\mathrm{M}$ et al. (2010) Arsenic exposure from drinking water, and all-cause and chronic-disease mortalities in Bangladesh (HEALS): a prospective cohort study Lancet 376:252-258 doi:10.1016/S01406736(10)60481-3

Bo S et al. (2008) Associations of dietary and serum copper with inflammation, oxidative stress, and metabolic variables in adults J Nutr 138:305-310 doi:10.1093/jn/138.2.305

Byun G, Kim S, Kim SY, Park D, Shin MJ, Oh H, Lee JT (2020) Blood Lead Concentrations and Mortality in Korean Adults: the Korea National Health and Nutrition Examination Survey with Mortality Follow-Up Int $J$ Environ Res Public Health 17 doi:10.3390/ijerph17186898

Chen K, Liao QL, Ma ZW, Jin Y, Hua M, Bi J, Huang L (2015) Association of soil arsenic and nickel exposure with cancer mortality rates, a town-scale ecological study in Suzhou, China Environ Sci Pollut Res Int 22:5395-5404 doi:10.1007/s11356-014-3790-y

Chen P, Bornhorst J, Aschner M (2018) Manganese metabolism in humans Front Biosci (Landmark Ed) 23:1655-1679 doi:10.2741/4665

Dorsey A, Ingerman L (2004) Toxicological profile for copper

Eshak ES, Iso H, Yamagishi K, Maruyama K, Umesawa M, Tamakoshi A (2018) Associations between copper and zinc intakes from diet and mortality from cardiovascular disease in a large population-based prospective cohort study J Nutr Biochem 56:126-132 doi:10.1016/j.jnutbio.2018.02.008

Faroon O, Ashizawa A, Wright S, Tucker P, Jenkins K, Ingerman L, Rudisill C (2012) Toxicological profile for cadmium

Gaetke LM, Chow CK (2003) Copper toxicity, oxidative stress, and antioxidant nutrients Toxicology 189:147-163 doi:10.1016/s0300-483x(03)00159-8

Genchi G, Sinicropi MS, Lauria G, Carocci A, Catalano A (2020) The Effects of Cadmium Toxicity Int J Environ Res Public Health 17 doi:10.3390/ijerph17113782 
Grammer TB et al. (2014) Copper, ceruloplasmin, and long-term cardiovascular and total mortality (the Ludwigshafen Risk and Cardiovascular Health Study) Free Radic Res 48:706-715 doi:10.3109/10715762.2014.901510

Huang $\mathrm{HH}$ et al. (2013) Cell-type specificity of lung cancer associated with low-dose soil heavy metal contamination in Taiwan: an ecological study BMC Public Health 13:330 doi:10.1186/1471-2458-13-330

Jaishankar M, Tseten T, Anbalagan N, Mathew BB, Beeregowda KN (2014) Toxicity, mechanism and health effects of some heavy metals Interdiscip Toxicol 7:60-72 doi:10.2478/intox-2014-0009

Jarup L (2002) Cadmium overload and toxicity Nephrol Dial Transplant 17 Suppl 2:35-39 doi:10.1093/ndt/17.suppl_2.35

Jarup L (2003) Hazards of heavy metal contamination Br Med Bull 68:167-182 doi:10.1093/bmb/ldg032 Jarup L, Akesson A (2009) Current status of cadmium as an environmental health problem Toxicol Appl Pharmacol 238:201-208 doi:10.1016/j.taap.2009.04.020

Khlifi R, Olmedo P, Gil F, Hammami B, Chakroun A, Rebai A, Hamza-Chaffai A (2013) Arsenic, cadmium, chromium and nickel in cancerous and healthy tissues from patients with head and neck cancer Sci Total Environ 452-453:58-67 doi:10.1016/j.scitotenv.2013.02.050

Lanphear BP, Rauch S, Auinger P, Allen RW, Hornung RW (2018) Low-level lead exposure and mortality in US adults: a population-based cohort study Lancet Public Health 3:e177-e184 doi:10.1016/S24682667(18)30025-2

Larsson SC, Wolk A (2016) Urinary cadmium and mortality from all causes, cancer and cardiovascular disease in the general population: systematic review and meta-analysis of cohort studies Int $\mathrm{J}$ Epidemiol 45:782-791 doi:10.1093/ije/dyv086

Leone N, Courbon D, Ducimetiere P, Zureik M (2006) Zinc, copper, and magnesium and risks for all-cause, cancer, and cardiovascular mortality Epidemiology 17:308-314

doi:10.1097/01.ede.0000209454.41466.b7

Li L, Yang X (2018) The Essential Element Manganese, Oxidative Stress, and Metabolic Diseases: Links and Interactions Oxid Med Cell Longev 2018:7580707 doi:10.1155/2018/7580707

Lightfoot N, Berriault C, Semenciw R (2010) Mortality and cancer incidence in a nickel cohort Occup Med (Lond) 60:211-218 doi:10.1093/occmed/kqp197

Lustberg M, Silbergeld E (2002) Blood lead levels and mortality Arch Intern Med 162:2443-2449 doi:10.1001/archinte.162.21.2443 
Madsen E, Gitlin JD (2007) Copper deficiency Curr Opin Gastroenterol 23:187-192 doi:10.1097/MOG.0b013e32801421bb

Meliker JR, Wahl RL, Cameron LL, Nriagu JO (2007) Arsenic in drinking water and cerebrovascular disease, diabetes mellitus, and kidney disease in Michigan: a standardized mortality ratio analysis Environ Health 6:4 doi:10.1186/1476-069X-6-4

Menke A, Muntner P, Silbergeld EK, Platz EA, Guallar E (2009) Cadmium levels in urine and mortality among U.S. adults Environ Health Perspect 117:190-196 doi:10.1289/ehp.11236

O'Neal SL, Zheng W (2015) Manganese Toxicity Upon Overexposure: a Decade in Review Curr Environ Health Rep 2:315-328 doi:10.1007/s40572-015-0056-x

Rehman K, Fatima F, Waheed I, Akash MSH (2018) Prevalence of exposure of heavy metals and their impact on health consequences J Cell Biochem 119:157-184 doi:10.1002/jcb.26234

Ruiz-Hernandez A, Navas-Acien A, Pastor-Barriuso R, Crainiceanu CM, Redon J, Guallar E, Tellez-Plaza M (2017) Declining exposures to lead and cadmium contribute to explaining the reduction of cardiovascular mortality in the US population, 1988-2004 Int J Epidemiol 46:1903-1912 doi:10.1093/ije/dyx176

Scheiber I, Dringen R, Mercer JF (2013) Copper: effects of deficiency and overload Met lons Life Sci 13:359-387 doi:10.1007/978-94-007-7500-8_11

Schober SE, Mirel LB, Graubard BI, Brody DJ, Flegal KM (2006) Blood lead levels and death from all causes, cardiovascular disease, and cancer: results from the NHANES III mortality study Environ Health Perspect 114:1538-1541 doi:10.1289/ehp.9123

Taylor AA, Tsuji JS, Garry MR, McArdle ME, Goodfellow WL, Jr., Adams WJ, Menzie CA (2020) Critical Review of Exposure and Effects: Implications for Setting Regulatory Health Criteria for Ingested Copper Environ Manage 65:131-159 doi:10.1007/s00267-019-01234-y

Tchounwou PB, Yedjou CG, Patlolla AK, Sutton DJ (2012) Heavy metal toxicity and the environment Exp Suppl 101:133-164 doi:10.1007/978-3-7643-8340-4_6

Tellez-Plaza M, Navas-Acien A, Menke A, Crainiceanu CM, Pastor-Barriuso R, Guallar E (2012) Cadmium exposure and all-cause and cardiovascular mortality in the U.S. general population Environ Health Perspect 120:1017-1022 doi:10.1289/ehp.1104352

Wang M, Xu Y, Pan S, Zhang J, Zhong A, Song H, Ling W (2011) Long-term heavy metal pollution and mortality in a Chinese population: an ecologic study Biol Trace Elem Res 142:362-379 doi:10.1007/s12011-010-8802-2

Wazir SM, Ghobrial I (2017) Copper deficiency, a new triad: anemia, leucopenia, and myeloneuropathy J Community Hosp Intern Med Perspect 7:265-268 doi:10.1080/20009666.2017.1351289 
Wen WL, Wang CW, Wu DW, Chen SC, Hung CH, Kuo CH (2020) Associations of Heavy Metals with Metabolic Syndrome and Anthropometric Indices Nutrients 12 doi:10.3390/nu12092666

Wu C, Woo JG, Zhang N (2017) Association between urinary manganese and blood pressure: Results from National Health and Nutrition Examination Survey (NHANES), 2011-2014 PLoS One 12:e0188145 doi:10.1371/journal.pone.0188145

Wu T, Sempos CT, Freudenheim JL, Muti P, Smit E (2004) Serum iron, copper and zinc concentrations and risk of cancer mortality in US adults Ann Epidemiol 14:195-201 doi:10.1016/S1047-2797(03)00119-4

\section{Tables}

Table 1. Comparison of clinical characteristics between the survivors and non-survivors

\begin{tabular}{|c|c|c|c|c|}
\hline Characteristics & All $(\mathrm{n}=2,497)$ & $\begin{array}{l}\text { Survival }(\mathrm{n}= \\
2457)\end{array}$ & Death $(n=40)$ & $p$ \\
\hline Age (year) & $54.3 \pm 14.0$ & $54.1 \pm 14.0$ & $69.1 \pm 11.4$ & $<$ \\
\hline $\begin{array}{l}\text { Male gender (\%) } \\
\text { DM (\%) } \\
\text { Hypertension (\%) } \\
\text { Hyperlipidemia (\%) }\end{array}$ & $\begin{array}{l}40.1 \\
10.3 \\
24.8 \\
2.2\end{array}$ & $\begin{array}{c}40.0 \\
9.9 \\
24.3 \\
2.2\end{array}$ & $\begin{array}{l}45.0 \\
32.5 \\
55.0 \\
2.5\end{array}$ & $\begin{array}{l}0.523 \\
0.005 \\
< \\
0.001\end{array}$ \\
\hline BMI $\left(\mathrm{kg} / \mathrm{m}^{2}\right)$ & $25.0 \pm 3.9$ & $25.0 \pm 3.9$ & $25.2 \pm 4.5$ & 0.912 \\
\hline SBP (mmHg) & $131.8 \pm 19.8$ & $131.7 \pm 19.7$ & $137.2 \pm 21.3$ & 0.083 \\
\hline DBP (mmHg) & $77.4 \pm 11.7$ & $77.4 \pm 11.7$ & $78.1 \pm 11.6$ & 0.691 \\
\hline $\begin{array}{l}\text { Laboratory parameters } \\
\text { Fasting glucose } \\
(\mathrm{mq} / \mathrm{dL})\end{array}$ & $99.6 \pm 27.2$ & $99.5 \pm 27.1$ & $106.9 \pm 31.7$ & 0.087 \\
\hline $\begin{array}{l}\text { Serum Creatinine } \\
\text { (mo/dL })\end{array}$ & $0.95 \pm 0.29$ & $0.94 \pm 0.28$ & $1.18 \pm 0.53$ & 0.007 \\
\hline $\begin{array}{l}\text { Triglyceride }(\mathrm{mg} / \mathrm{dL}) \\
\text { Total cholesterol }\end{array}$ & $\begin{array}{l}126.1 \pm 97.4 \\
199.2 \pm 37.5\end{array}$ & $\begin{array}{l}126.0 \pm 97.3 \\
199.3 \pm 37.4\end{array}$ & $\begin{array}{c}138.2 \pm 100.2 \\
191.4 \pm 43.3\end{array}$ & $\begin{array}{l}0.428 \\
0.186\end{array}$ \\
\hline $\begin{array}{l}\text { HDL-cholesterol } \\
(\mathrm{mg} / \mathrm{dL})\end{array}$ & $53.0 \pm 13.6$ & $53.0 \pm 13.6$ & $50.5 \pm 15.4$ & 0.237 \\
\hline $\begin{array}{l}\text { LDL-cholesterol } \\
\text { (mg/dL) }\end{array}$ & $118.9 \pm 34.0$ & $119.1 \pm 33.9$ & $108.4 \pm 36.1$ & 0.048 \\
\hline $\begin{array}{l}\mathrm{Pb}(\mathrm{mg} / \mathrm{dL}) \\
\text { Urine }\end{array}$ & $1.5(1.0-2.2)$ & $1.8(1.0-2.2)$ & $2.1(1.3-2.8)$ & 0.201 \\
\hline $\mathrm{Cd}(\mathrm{mg} / \mathrm{L})$ & $0.8(0.3-1.4)$ & $1.1(0.2-1.4)$ & $1.5(0.5-2.4)$ & 0.017 \\
\hline $\mathrm{Ni}(\mathrm{mg} / \mathrm{L})$ & $2.5(1.5-3.7)$ & $3.3(1.5-3.7)$ & $3.8(1.9-5.4)$ & 0.829 \\
\hline $\mathrm{Cu}(\mathrm{mg} / \mathrm{dL})$ & $1.5(1.0-2.0)$ & $1.6(1.0-2.0)$ & $2.55(1.5-3.6)$ & $<$ \\
\hline $\begin{array}{l}\mathrm{Cr}(\mathrm{mg} / \mathrm{L}) \\
\mathrm{Mn}(\mathrm{mg} / \mathrm{L}) \\
\text { As }(\mathrm{mg} / \mathrm{L})\end{array}$ & $\begin{array}{c}0.1(0.1-0.1) \\
1.7(0.9-3.0) \\
77.9(44.5- \\
140.2)\end{array}$ & $\begin{array}{c}0.1(0.1-0.1) \\
2.2(0.9-3.0) \\
118.2(44.0- \\
139.4)\end{array}$ & $\begin{array}{c}0.1(0.1-0.1) \\
1.5(0.6-2.0) \\
159.9(69.9- \\
205.4)\end{array}$ & $\begin{array}{l}0.787 \\
0.019 \\
0.064\end{array}$ \\
\hline
\end{tabular}

Abbreviations. DM, diabetes mellitus; BMI, body mass index; SBP, systolic blood pressure; DBP, diastolic blood pressure; HDL, high-density lipoprotein; LDL, low-density lipoprotein; 
$\mathrm{Pb}$, lead; $\mathrm{Cd}$, cadmium; $\mathrm{Ni}$, nickel; $\mathrm{Cu}$, copper; $\mathrm{Cr}$, chromium; $\mathrm{Mn}$, manganese; As, arsenic.

Table 2. Predictors of overall mortality using Cox proportional hazards model

\begin{tabular}{|c|c|c|}
\hline \multirow[t]{2}{*}{ Parameters } & \multicolumn{2}{|c|}{ Univariable analysis } \\
\hline & HR (95\% CI) & $p$ \\
\hline Age (per 1 year) & $1.097(1.066-1.128)$ & $<0.001$ \\
\hline Male (vs. female) & $1.259(0.675-2.347)$ & 0.469 \\
\hline DM & $4.049(2.089-7.848)$ & $<0.001$ \\
\hline Hypertension & $3.478(1.865-6.485)$ & $<0.001$ \\
\hline Hyperlipidemia & $1.193(0.164-8.685)$ & 0.862 \\
\hline BMI (per $1 \mathrm{ko} / \mathrm{m}^{2}$ ) & $1.007(0.929-1.090)$ & 0.873 \\
\hline SBP (per $1 \mathrm{mmHg}$ ) & $1.012(0.998-1.027)$ & 0.090 \\
\hline DBP (per $1 \mathrm{mmHg}$ ) & $1.007(0.981-1.033)$ & 0.615 \\
\hline \multicolumn{3}{|l|}{ Labortaory data } \\
\hline Fasting glucose (per $1 \mathrm{mg} / \mathrm{dL}$ ) & $1.006(0.998-1.014)$ & 0.141 \\
\hline Creatinine (per $1 \mathrm{mg} / \mathrm{dL}$ ) & $1.998(1.482-2.695)$ & $<0.001$ \\
\hline Total cholesterol (per $1 \mathrm{mg} / \mathrm{dl}$ ) & $0.994(0.985-1.002)$ & 0.155 \\
\hline Triglyceride (per 1 mg/dL) & $1.001(0.999-1.003)$ & 0.366 \\
\hline HDL-cholesterol (per $1 \mathrm{mg} / \mathrm{dL}$ ) & $0.986(0.962-1.010)$ & 0.254 \\
\hline LDL-cholesterol (per 1 mg/dL) & $0.990(0.980-0.999)$ & 0.037 \\
\hline \multicolumn{3}{|l|}{ Blood } \\
\hline $\mathrm{Pb}($ per $1 \mathrm{mg} / \mathrm{dL})$ & $1.067(0.931-1.222)$ & 0.350 \\
\hline \multicolumn{3}{|l|}{ Urine } \\
\hline Cd (per $1 \mathrm{mg} / \mathrm{L})$ & $1.290(1.070-1.554)$ & 0.008 \\
\hline $\mathrm{Ni}($ per $1 \mathrm{mg} / \mathrm{L})$ & $1.001(0.989-1.013)$ & 0.866 \\
\hline $\mathrm{Cu}($ per $1 \mathrm{mg} / \mathrm{dL}$ & $1.378(1.241-1.529)$ & $<0.001$ \\
\hline Cr (per 1 mg/L) & $1.101(0.534-2.268)$ & 0.795 \\
\hline $\mathrm{Mn}($ per $1 \mathrm{mg} / \mathrm{L})$ & $0.726(0.567-0.930)$ & 0.011 \\
\hline As (per $1 \mathrm{mg} / \mathrm{L}$ ) & $1.001(1.000-1.003)$ & 0.127 \\
\hline
\end{tabular}

Values expressed as hazard ratio (HR) and 95\% confidence interval (CI). Abbreviations are the same as in Table 1.

Table 3. Association of heavy metals with overall mortality using multivariate Cox proportional hazards model 


\begin{tabular}{lcc}
\hline Heavy metals & \multicolumn{2}{c}{ Multivariable } \\
\cline { 2 - 3 } & HR (95\% CI) & $p$ \\
\hline $\begin{array}{c}\text { Blood } \\
\text { Pb (per } 1 \mathrm{mg} / \mathrm{dL})\end{array}$ & $1.024(0.865-1.231)$ & 0.780 \\
\hline Urine & $1.352(1.089-1.680)$ & 0.006 \\
$\mathrm{Cd}($ per $1 \mathrm{mg} / \mathrm{L})$ & & \\
$\mathrm{Ni}($ per $1 \mathrm{mg} / \mathrm{L})$ & $1.004(0.990-1.018)$ & 0.599 \\
$\mathrm{Cu}($ per $1 \mathrm{mg} / \mathrm{dL})$ & $1.350(1.151-1.583)$ & $<0.001$ \\
$\mathrm{Cr}($ per $1 \mathrm{mg} / \mathrm{L})$ & $1.015(0.513-2.009)$ & 0.966 \\
\hline $\mathrm{Mn}($ per $1 \mathrm{mg} / \mathrm{L})$ & $0.717(0.557-0.923)$ & 0.010 \\
\hline $\mathrm{As}($ per $1 \mathrm{mg} / \mathrm{L})$ & $1.001(0.999-1.003)$ & 0.424 \\
\hline
\end{tabular}

Values expressed as hazard ratio (HR) and 95\% confidence interval (CI). Abbreviations are the same as in Table 1.

Covariates in the multivariable model included age, sex, DM, hypertension, creatinine, and LDL-cholesterol. 